\title{
Organic Removal Treatment Using Microbubble Generator (MBG) in Eutrophic Disorder Condition
}

\author{
Tri Yulianti ${ }^{1, *}$, Sri Puji Saraswati ${ }^{1}$, Johan Syafri Mahathir Ahmad ${ }^{1}$, Wiratni Budhijanto ${ }^{2}$ \\ ${ }^{1}$ Department of Civil and Environmental Engineering, Universitas Gadjah Mada, Yogyakarta, INDONESIA, \\ Jalan Grafika No 2 Yogyakarta \\ ${ }^{2}$ Department of Chemical Engineering, Universitas Gadjah Mada, Yogyakarta, INDONESIA, \\ Jalan Grafika No 2 Yogyakarta \\ *Corresponding authors: triyulianti@mail.ugm.ac.id
}

SUBMITTED 27 June 2021 REVISED 18 October 2021 ACCEPTED 26 October 2021

\begin{abstract}
The Techno Park basin, built as an extension of a small tributary of the Code River primarily acts as a retention basin for runoff during the rainy season. It improves the quality of water that has been degraded by domestic wastewater discharge from the surrounding community. Therefore, this study aims to assess the extent to which water quality of the basin can be improved with aeration technology. The aeration technology is a Microbubble Generator (MBG) built using a 100 Watts submersible pump with three horizontal nozzles at a depth of $40 \mathrm{~cm}$ from the water surface. Furthermore, the profiles of dissolved oxygen (DO) concentration were measured at the basin's inlet and outlet, as well as the depths of $1 \mathrm{~m}$ below surface water and the bottom of the basin. Diurnal DO was measured to investigate the causes of supersaturation. The aeration performance was also determined from the COD parameters at the inlet and outlet. Discharge measurements were then conducted on the tributary/drainage channel to the inlet basin. The result showed that the DO supersaturation concentration has been attributed to the contribution of photosynthesis from phytoplankton such as algae. Furthermore, no change in DO concentration was observed in a range of $1 \mathrm{~m}$ depth from the surface of the water to the bottom ( $0.3-0.14 \mathrm{mg}-\mathrm{DO} / \mathrm{I})$. In this eutrophic state, DO increased exponentially during the daytime hours and then decreased during the night. The daily measurement showed an increase in the average DO of $2.31 \mathrm{mg} / \mathrm{l}$ (standard deviation of $1.56 \mathrm{mg} / \mathrm{l}$ ), with average CODinlet fluctuations of $18.79 \mathrm{mg} / \mathrm{l}$ (standard deviation of $13.56 \mathrm{mg} / \mathrm{l}$ ) and average CODoutlet of $14.38 \mathrm{mg} / \mathrm{l}$ (standard deviation $2.94 \mathrm{mg} / \mathrm{l}$ ). Due to additional DO concentration coming from eutrophication during daylight, it was not possible to make a precise assessment of the effectiveness of the MBG aerator.
\end{abstract}

KEYWORDS Aerator; DO Concentration; Eutrophic Condition; Microbubble Generator; Organic Load (COD).

(c) The Author(s) 2022. This article is distributed under a Creative Commons Attribution-ShareAlike 4.0 International license.

\section{INTRODUCTION}

The Techno Park has two retention basins built in-line with a tributary of the Code River in the area of the Gadjah Mada University (UGM) Faculty of Engineering. Primarily, this basin functions as a container for grey water from people living around the tributary or drainage channel. During the first observation, the current was relatively the same every day, but the water quality status fluctuated. The water condition is poor and contains detergents or household soaps, resulting in bubbles, color, and odor, which are also indicative of excessive organic pollution. Furthermore, the tributary that flows into the Code River is influenced by the quality of the water flowing out of the basin.
The status of the Code River water quality has exceeded the class II standard in the downstream section based on the report of the 2018 Yogyakarta City Environment Service. A 98\% of the pollution load comes from the domestic sector following the calculation of water quality parameters using the Storet Method. Sulistyo \& Puji (2018) examined the water quality status of the Code River from 2007 to 2016 using the IP and Storet method. The results obtained classified the river as heavily polluted based on the class II Indonesia Government Regulation No. 82 of 2001. This organic load should be reduced to improve the water quality of the basin before entering the Code River. 
The decrease in dissolved oxygen (DO) levels is one of the detrimental effects caused by the disposal of organic waste, with the concentration of DO being one of the most important indicators of self-purification of a water body (Huhnke, 2018). Furthermore, the rapid decline of oxygen will indirectly pose a threat to the life of flora and fauna in the water, and this type of condition is also a conducive place for bacterial growth. An increasing organic load in a body of water will be balanced by an increase in microorganisms to break down the organic content. However, oxygen will be consumed in the process, thereby decreasing the level of dissolved oxygen (DO) in the water (Dionisi, 2017).

Since organic load needs to be reduced to improve the water quality of the basin, the amount of DO in water should also be maintained. Oxygen in waters can be available through natural oxygen transfer processes (aeration), such as through increasing velocity flow to increase air contact with water, or through artificial reaeration. The natural aeration process was slow in the basin due to the reduced (laminar) flow of water. Therefore, reaeration should be conducted to increase the DO concentration, and in this study, the process was used as a diffuser aerator system in the form of a Microbubble Generator (MBG). It provided more oxygen for the microorganisms to decompose organic material, thereby increasing the water quality discharged into the Code River. Meanwhile, the MBG was applied as a solution to solve leachate in Sanitary Landfill and performed an efficient as well as less energy consumed technology. A pond with a volume of $75 \mathrm{m3}$ discharged at $8 \mathrm{~m} 3 /$ hour performed effectively to increase the level of Dissolved Oxygen (DO) and to decrease the level of Chemical Oxygen Demand (COD) to about 15,3\% and 16,2\% respectively (Pradana et al., 2016). Therefore, this study aims to analyze the extent to the MBG performance can increase DO concentration and reduce the concentration of organic pollutants in the basin.

\section{METHODS}

\subsection{Installation of MBG aerator at the basin I}

There are two basins built in the Engineering Faculty of Gadjah Mada University (UGM) area. The aim of the study and data collection was carried out at the first basin.

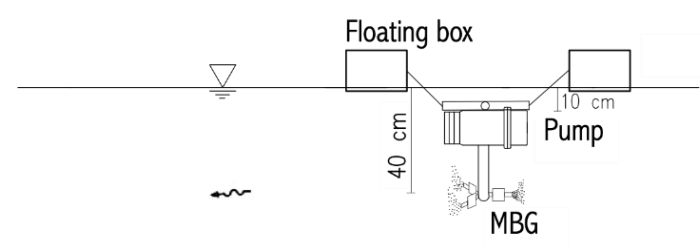

(a)

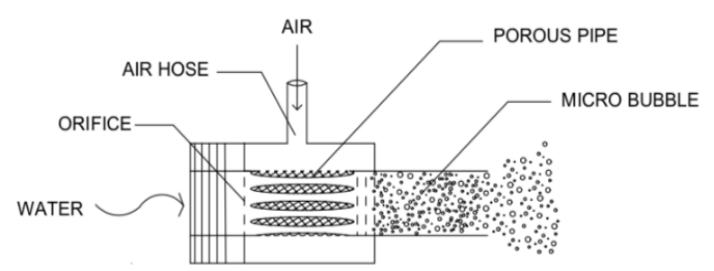

(b)

Figure 1. (a) Location of the measurement of discharge; (b) The position of the MBG from the longitudinal section of the basin; (c) MBG Nozzle

The surface area of the water basin was $950 \mathrm{~m}^{2}$ with a volume of about $700 \mathrm{~m}^{3}$ and the efficiency of reducing COD depends on the flow rate of the air sucked into the MBG. The smaller the air suction rate, the more effective COD removal. However, an extremely low suction rate can also make the MBG less stable (Budhijanto, et al., 2015) due to the high collisions between the bubbles. The position of the MBG in the aerobic wastewater treatment pond should be designed to minimize the tendency of collisions between bubbles. Furthermore, the MBG was set at a depth of $40 \mathrm{~cm}$ in the middle of the basin to reduce the blockage of the pump filter by the large amount of waste entering the basin inlet as shown in Figure 1(a) (Kurniawan, 2019). 
The submersible pump used was Lifetech SP608 with a pumping rate of 100 Watt, and the MBG aerator used was an ejector type with an inlet and outlet diameter of $25.4 \mathrm{~mm}$ (1 inch) and $15 \mathrm{~mm}$ (Figure $1 \mathrm{~b}$ ) respectively. The aerator has an air suction hole of $3 \mathrm{~mm}$ in diameter with a flow rate ranging from $0.1-0.6 \mathrm{l} / \mathrm{min}$ to generate microbubbles. The inner core comprised of a hollow porous pipe wrapped with gauze cloth and this allows the air entering through the suction hole to form small bubbles. Water pumped into the aerator will flow through a narrowing hole in the porous pipe to increase the speed of the flow and create negative pressure by decreasing the diameter. The presence of this negative pressure causes the air sucked through a porous hole to form microbubbles that dissolve into the water (Deendarlianto, et al., 2015; Shalindry, et al., 2015). In addition, the MBG used in this study had three nozzles.

\subsection{Data collection}

The study continued for 10 days from September 20, 2019 (dry season) and began when signs of algal growth appeared after 1.5 months of gray water flowing through the basin. A series of measurements were conducted each day between approximately 1:00 p.m. and 3:00 p.m, and it is considered as a continuation of a previous study (Yulianti et al., 2019). Furthermore, data were collected to monitor the water quality changes as a result of re-aeration, and the MBG was operated continuously during the entire 10 days of data collection. In waters without eutrophic conditions, the maintenancefree MBG can only be operated for a maximum of 2 weeks. On the 11th day, one of the three installed MBG nozzles were reported to be clogged when the water turned eutrophic. The floc film was formed on the pump filter, and this was caused by a large number of suspended particles in the water following the increased turbidity, making it easy to cause blockages.

In situ measurements were made for discharge and DO concentrations. The discharge was measured at the outlets of the drainage channel from both Selokan Mataram and Kaliurang Street water sources. This was conducted using OTT C2 current meters based on the Mean Area Method (Lin, 2007); Indonesia National Standard (SNI) 8066: 2015 (Standard National Agency, 2015). In addition, the profile of DO stratification was measured by manually lowering down a probe connected to the meter (Lutron WA-2017SD) and recording a measurement every $1 \mathrm{~m}$ from the water surface to the basin floor. The DO was measured also at the basin inlet and outlet at a depth of $5 \mathrm{~cm}$ from the water surface. The results were plotted using the Surfer application to obtain a vertical DO distribution profile in the basin water.

Diurnal measurements were made on-site using the same DO meter type from the sixth day of the study for 5 days. The mass transfer reaction of DO in 24 four hours was described in a graph (shown at Figure 3).

a. Each ascending part curve indicates the aeration of MBG and the results of photosynthesis of algae were far greater than the oxygen requirements for organic decomposition (COD) and algal respiration.

$$
\begin{aligned}
& \frac{d \mathrm{O}_{2}}{d t}=\text { reoxygenation }- \text { deoxygenation } \\
& \frac{d \mathrm{O}_{2}}{d t}=(\mathrm{MBG}+\text { algal photosynthesis })- \\
& (\mathrm{COD} \text { removal }+ \text { algal respiration })
\end{aligned}
$$

b. Each descending part of the curve shows oxygen consumption for organic decomposition (COD) and algal respiration greater than the amount of aeration of the MBG.

$$
\begin{aligned}
\frac{d \mathrm{O}_{2}}{d t}= & \text { reoxygenation }- \text { deoxygenation } \\
\frac{d \mathrm{O}_{2}}{d t}= & M B G-(\mathrm{COD} \text { removal }+ \\
& \text { algal respiration })
\end{aligned}
$$

These automatically logged measurements only monitored DO concentrations, and there were no COD records in the field. The decrease in DO (downward curve) cannot be viewed in terms of the quantity of oxygen needed for depletion by microorganisms or plant respiration. Meanwhile, the measure of the oxygen used to decompose organic and inorganic matter chemically in 
wastewater was COD. Water samples were taken at the basin inlet and outlet and were analyzed in the Laboratory of Sanitary Engineering DTSL FT UGM to determine COD based on Indonesia National Standard (SNI) 06-6989.22-2004 (Standard National Agency, 2004). Subsequently, in situ DO data and COD analysis at the inlet and outlet were represented in graphical form in Excel.

\section{RESULTS AND DISCUSSIONS}

\subsection{DO Stratification}

Initially, DO measurements were obtained after the aerator has worked for 24 hours. Data retrieval was conducted once a day and the depth of the basin measured in the field was $1.90 \mathrm{~m}$. The DO stratification from the surface to the bottom was calculated close to the MBG as shown in Figure 2.

Two different regions were evident; First, at depths less than $1 \mathrm{~m}$, there was no systematic change in oxygen levels throughout the study. A range of increased DO was observed, from supersaturation at the surface $(>8 \mathrm{mg} / \mathrm{l})$ down to a depth of approximately $80 \mathrm{~cm}$ with aerobic condition (DO levels $>2 \mathrm{mg} / \mathrm{l}$ ) in the second region. This can be explained by assuming that the cause of increased DO of the water was eutrophication since algae or another chlorophyll aquatic plant only float down to a certain depth about $60 \mathrm{~cm}$ below the surface of the water, where there is still intensity of sunlight (Lin, 2007).

This anoxic state (DO concentration <2 $\mathrm{mg} / \mathrm{l}$ ) requires further evaluation concerning the use of MBG. Even though the aerator was operated continuously for 24 hours, it was not sufficient to increase DO concentration in the depth of the water compared to that of the basin $(1,93 \mathrm{~m})$. Continuation of this condition can dramatically decrease the ability of aerobic bacteria to break down organic load (in terms of aerobic treatment). The aerobic microorganisms may die in very low DO conditions that can lead to anaerobic processes and cause odor in the water. The DO level sufficient for bacterial survival depends on the type of microorganism and temperature. Heterotrophic bacteria can survive in very low DO (0.1 - $0.7 \mathrm{mg} / \mathrm{l})$ while autotrophic bacteria cease their activities when DO is below $1.5 \mathrm{mg} / \mathrm{l}$. Therefore, DO concentrations in waters should be above $2 \mathrm{mg} / \mathrm{l}$ (Winkler, 1981) to maintain aerobic conditions.

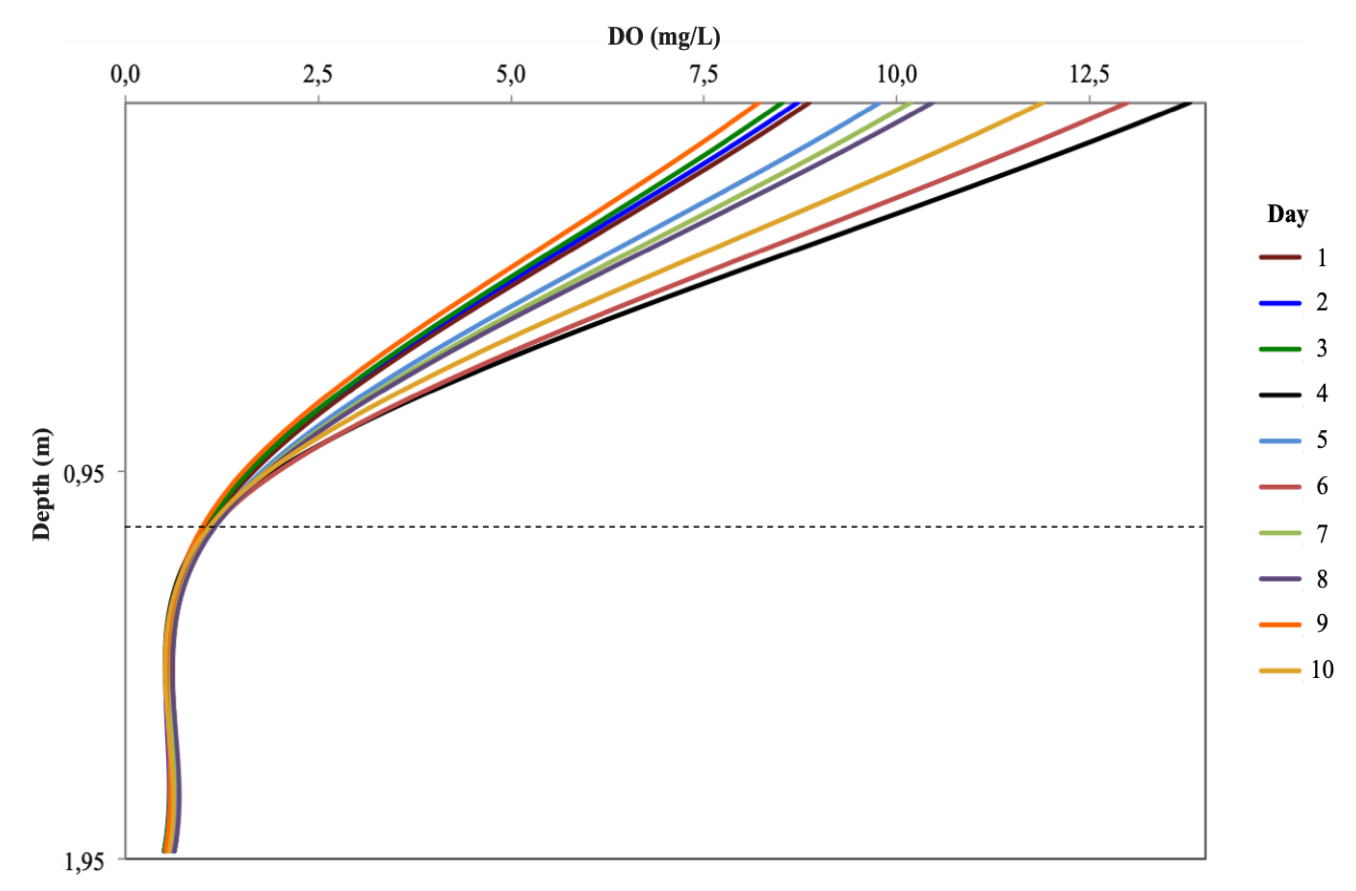

Figure 2. DO stratification measured 


\subsection{DO Diurnal Variation}

Figure 3 showed the diurnal variation of DO concentration, where the levels may reach supersaturation at certain times of the day. Furthermore, the measured DO curve showed the result of the mass transfer reaction for 5 days in the basin water. The aim of the measurement, which lasted up to day 11 , was to monitor the concentration without interrupting the apparatus for measuring the area and the vertical OD around the MBG of the previous days.

As an indication of eutrophication, the observation of an increase in the oxygen content during the day with high light intensity can be interpreted in contrast to the marked decrease at night. Eutrophication is caused by the growth of phytoplankton (micro-sized water plants containing chlorophyll) such as moss or algae, which utilize high-intensity light in a digestion process (photosynthesis) (Lin, 2007). Meanwhile, oxygen as a byproduct of photosynthesis increases the level of DO independent of the MBG. The absence of sunlight at night halts photosynthesisbut phytoplankton and bacterial activity in the sediments still need oxygen for respiration. This is because high respiration levels relative to the oxygen supply from the MBG result in the night time decrease of DO concentration as seen in Figure 4.

The three main processes causing fluctuations in DO concentrations are photosynthesis, respiration, and reaeration (Correa-Gonzales, et al., 2014; Boyd, 2018).
These conditions need to be considered for the operation of the MBG in the basin. The use of an aerator unit with 3 MBG nozzles with 100 watts of electricity cannot increase or maintain DO concentration during the night and in the lower depths of the basin water. Furthermore, dissolved oxygen input should be greater than the amount required for respiration by the water reservoir's nighttime biota activity to avoid anoxic conditions. For this, additional aerators can be added to increase DO, and in return, the electrical power required will be increased.

An alternative to increasing the number of aerators is to counter-intuitively turn off the MBG at night. As a result, the oxygen supply is interrupted and the respiration process of the aquatic plants is disturbed, which leads to a reduction in reproductive activities. Aerobic bacteria can then be developed since the aquatic plants use less nighttime oxygen. One additional advantage of this method is that the nitrification-denitrification process improves by alternately creating aerobic and anaerobic conditions of the basin. This process produces a stable $\mathrm{N}$ product that can evaporate into the air to reduce the nitrogen content in the water and indirectly limit eutrophication. Running the MBG aerator for a long duration can form flocks that block the MBG nozzle filter. Therefore, it should be operated on/off only in periods of 30 minutes to minimize this effect (Pradana et al., 2016). This means that when the MBG is turned off at night, the device should be cleaned more frequently.

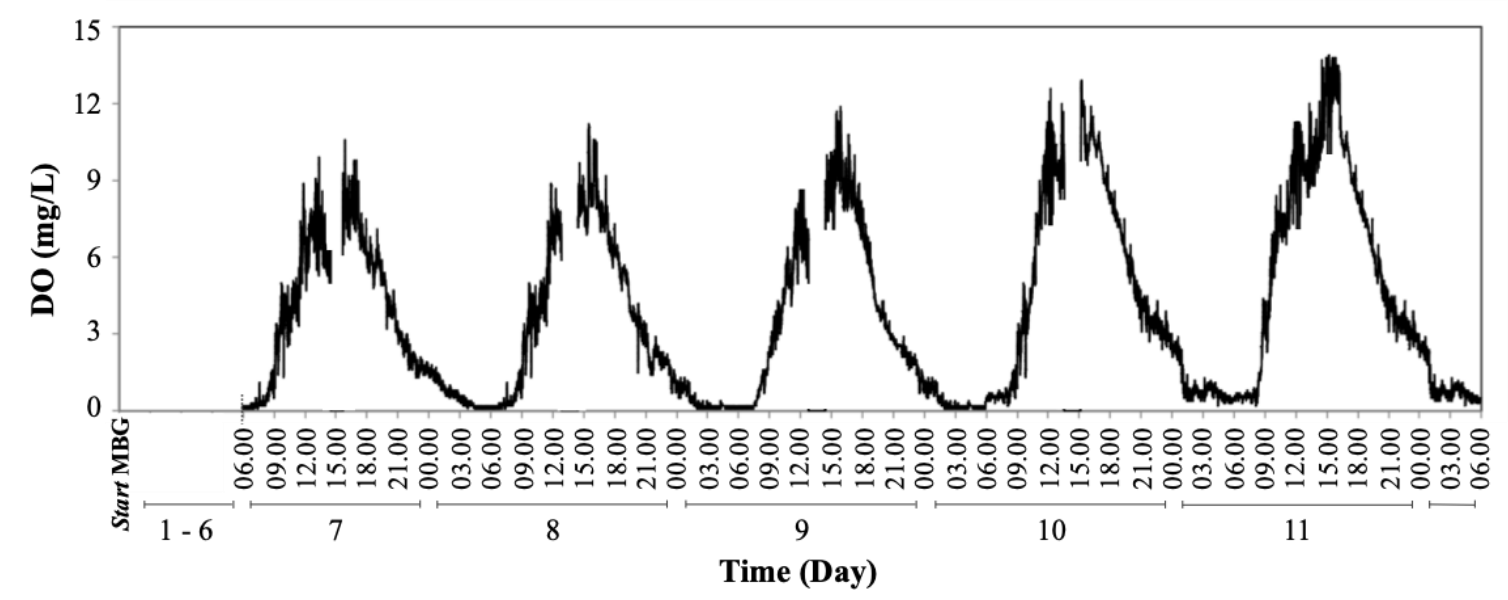

Figure 3. Changes in diurnal DO concentration 


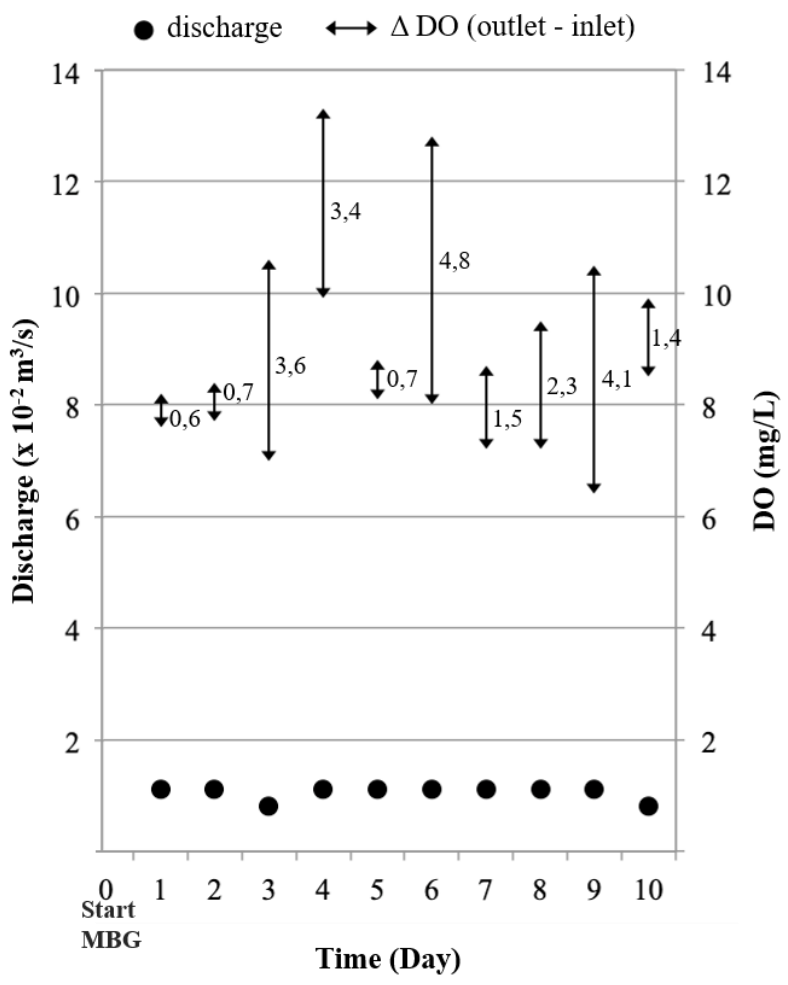

(a)

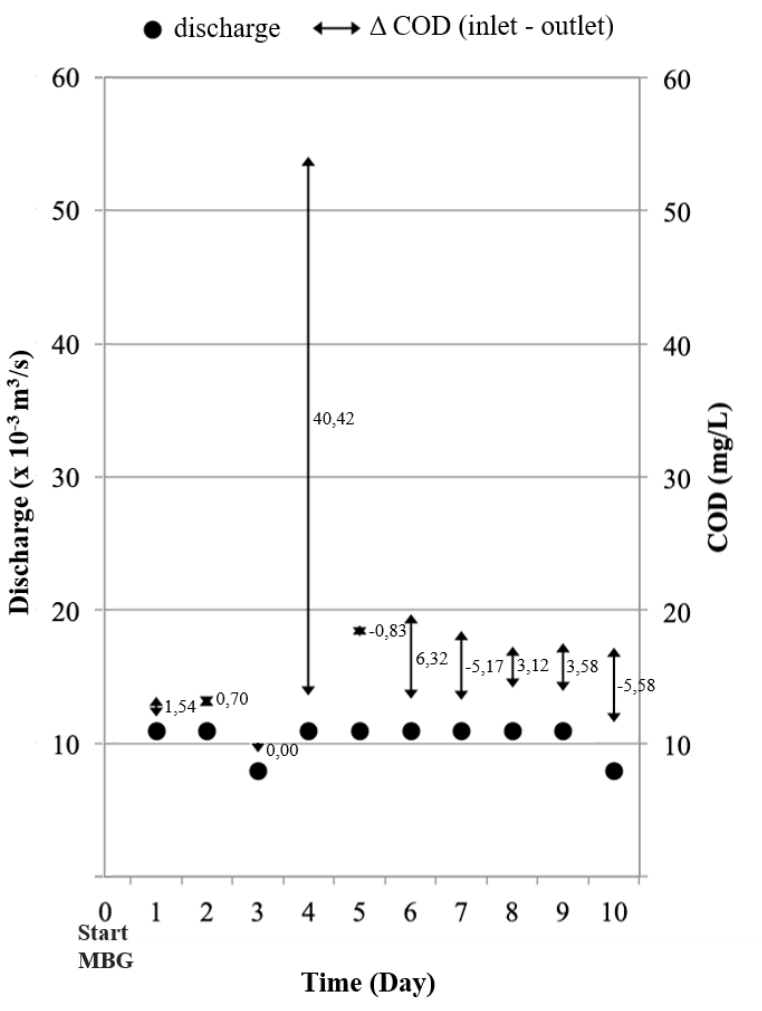

(b)

Figure 4. (a) Changes in DO concentration at the inlet and outlet; (b) The COD changes at the inlet and outlet

3.3 DO and COD Concentration at the Basin's Inlet and Outlet

Previous studies showed that an average increase in DO concentration at around $1 \mathrm{mg} / \mathrm{l}$ (standard deviation of $0.30 \mathrm{mg} / \mathrm{l}$ ) and $30 \%$ of the COD was removed during the first week of using the MBG. The initial COD concentration in the inlet of the basin was $33.33 \mathrm{mg} / \mathrm{l}$ ), and the concentration of COD (organic load) entering the pond will not directly affect the growth of aquatic plants. However, the concentration of organic load contributed to the increase in aerobic bacteria, and this caused high COD removal efficiency. The results of the decomposition of organic loads will increase the level of $\mathrm{CO}_{2}$ in the water which is indirectly used by phytoplankton to grow and conduct photosynthesis. To a certain extent, algae have developed rapidly in water bodies and with high adaptability to the basin environment. Furthermore, the algae will continue to develop well on daylight to enable eutrophication (Yulianti et al., 2019).
These eutrophication conditions cause variation of DO and COD concentrations at the inlet in the range of $6.4 \mathrm{mg} / \mathrm{l}-9.9 \mathrm{mg} / \mathrm{l}$ and $9.57 \mathrm{mg} / \mathrm{l}-54.04$ $\mathrm{mg} / \mathrm{l}$ respectively. Meanwhile, the resulting fluctuations for DO and COD removal were measured at the outlet as $7.89 \%-64.04 \%$ and $0 \%$ - 74.80\% (Figure 4). The DO concentrations in the water basin were sufficient for the removal of COD. However, the opposite case was also observed with an increase in COD concentration at the outlet. The COD analysis over the test period showed that there were several days when increased levels of DO is not necessary for decomposing the organic load. For example, on the $3^{\text {rd }}$ day of measurement, when the change in DO concentration was high there was no change in COD at the outlet from the inlet. The COD removal cannot be predicted as the increase in DO concentration is also unpredictable. In addition, the organic load was more concentrated and very difficult to degrade due to decreased discharge from 0.025 to $0.011 \mathrm{~m}^{3} / \mathrm{s}$ over 10 days of measurements. This can also cause an indirect decrease in the ability of COD removal in water. The declining effectiveness of 
COD removal with increased DO supersaturation can be explained from the results study of Handayani (2016). Furthermore, the interaction of aerobic bacteria in microalgae ponds (chlorophyll aquatic plants) was identified with indicators focusing on the relationship between levels of COD and DO. It has been explained that aerobic bacteria and aquatic plants can exist in symbiosis during the day. This is because chlorophyll plants and/or algae use light and carbon dioxide to photosynthesize and produce oxygen used by bacteria to oxidize organic compounds and produce carbon dioxide. Algae will continue to strive in a pond that they have adapted to the local environment even with a low organic load. Meanwhile, this resulting DO concentration during the day can be very high, and at night the water may still become anoxic. This is because there is no ongoing photosynthesis process since aquatic plants need oxygen to respire.

Since DO concentrations of the surface water at night were measured to be anoxic (Figure 4), the lower depths of the basin were likely in anaerobic conditions while the aerobic bacteria cannot survive there. This is one of the factors leading to the decreasing organic decomposition observed; despite the increase in DO from the MBG aeration process, the non-availability of bacteria that have died before can decrease COD removal (Handayani, 2016). The death of many bacteria in the waters has contributed to the amount of decomposed organic load. Therefore, on the fourth day, the COD removal was high while the concentration was reduced to $40.42 \mathrm{mg} / \mathrm{l}$. This was the result of the accumulation of dead bacteria from previous days.

\section{CONCLUSION}

The condition of the basin showed the onset of eutrophication within just 1.5 months without additional maintenance. This has an impact on the fluctuation of COD removal and DO diurnal concentration. Furthermore, the basin water gets additional DO from the photosynthesis of algae during the daytime. However, since the respiratory processes of all the biota are increased at night following the uptake of MBG, the OD level will be drastically reduced to anoxic conditions. By turning the MBG off at night, plant respiration and the nitrification-denitrification processes can be disrupted to also reduce energy usage. Meanwhile, turning the aerator off for more than 30 minutes can cause the formation of filming in the nozzle. This will result in a blockage, leading to an increased frequency of cleaning MBG.

These measurements showed a precise assessment of the effectiveness of the aeration system by MBG in removing organic pollutants due to eutrophication. Oxygen is supplied from other sources (such as eutrophication), but this will depend on the amount of discharge water entering the basin. During the study, the slow water flow increased eutrophication and DO concentration.

\section{DISCLAIMER}

The authors declare no conflict of interest.

\section{AVAILABILITY OF DATA AND MATERIALS}

All data are available from the author.

\section{AUTHOR CONTRIBUTION STATEMENTS}

Author Wiratni B provided the MBG aerator and equipments' needed for the research. Author Tri Y set up and carried out the experimental test, collected and analyzed field sample collection, while all authors analyzed the data result, contributed on discussing the result and drafting the manuscript.

\section{ACKNOWLEDGMENTS}

The authors are grateful to the Chemical Engineering Department of the Faculty of Engineering Gadjah Mada University for the procurement of MBG aerators and the licensing of the Faculty of Engineering in conducting the study at the Techno Park basin.

\section{REFERENCES}

APHA, 2005. Standard Method fo the Examination of Water and Wastewater, 21st Edition. s.l.:American Public Health Association (APHA).. 
Boyd, C., 2018. Dissolved oxygen dynamics, s.l.: Global Aquaculture Advocate.

BSN, 2004. Water and Wastewater - Part 22: How to Test the Permanganate Value by Titrimetry. SNI 06-6989.22-2004. s.l.:Indonesia National Standard Agency (BSN).

BSN, 2015. Procedures for Measurement of River Flow Discharge and Open Channels Using Flow and Buoy Measuring Devices. SNI 8066: 2015. s.l.:Indonesia National Standardization Agency (BSN).

Correa-Gonzales, J., Chavez-Parga, M., Cortes, J. \& Perez-Munguia, R., 2014. Photosynthesis, Respiration and Reaeration in a Stream with Complex Dissolved Oxygen Pattern and Temperature Dependence. Ecological Modelling, Volume 273, pp. 220-227.

Deendarlianto, W., Tontowi, A., \& Indarto, A., 2015. The Implementation of a Developed Microbubble Generator on The Aerobic Wastewater Treatment. International Journal of Technology, Volume 6, pp. 924-930.
Dionisi, D., 2017. Biological Wastewater Treatment Process. Mass and Heat Balances. s.l.:CRC Press, Taylor and Francis Group.

Handayani, E., 2016. Liquid Waste Management with Microalgae Pond Systems: Effect of COD concentration on the Oxygen Supply Adequacy. Yogyakarta: Gadjah Mada University.

Lin, S., 2007. Water and Wastewater Calculations Manual 2 nd-Edition. s.l.: McGraw-Hill.

Pradana, M., Fitriyadi, N., Hans, A., \& Dridya, M.A., 2016. Testing the Capability and the Energy Consumption of Micro-Bubble Generators in the Leachate of Wastewater Treatment Process at TPST Piyungan, Bantul, Yogyakarta. Yogyakarta, Department of Mechanical and Industrial Engineering, Engineering Faculty, UGM, pp. 166171.

Sawyer, C., McCarty, P. \& Parkin, G., 2003. Chemistry for Environmental Engineering and Science 5 th Edition. s.l.:McGraw-Hill.

Winkler, M., 1981. Biological Treatment of WasteWater. s.l.: Ellis Horwood. 